\title{
Synthesis of Some 1,4-Bis (Substituted 1,3,4- Oxadiazoles and 1,2,4-Triazoles) Benzene From Terephthalic Acid
}

\section{K. M. Daoud \& $\quad$ E. Q. Mahmood \& $\quad$ M. Y. Salih Department. of Chemistry / College of Education University of Mosul}

Received
$02 / 02 / 2011$

\author{
Accepted \\ 09 / 05 / 2011
}

\section{الملخص}

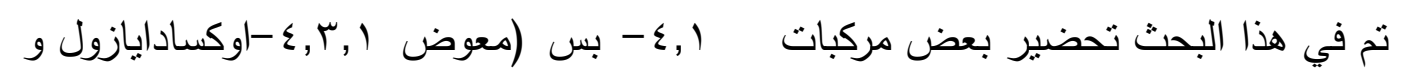

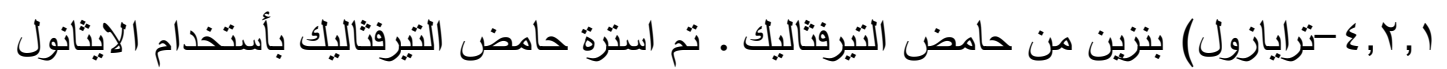
المطلق بوجود حامض الكبريتيك المركز الى تيرفتالات الاثيل (1) والذي تم تحويله الى هيدرازيد

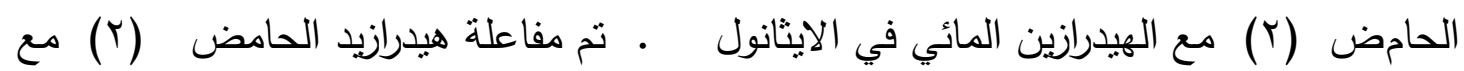
ايسوثايوسيانات الفنيل واعطى معوض ثايوسيمكاربازيد (ع) بينما اعطى تفاعله مع ثايوسيانات

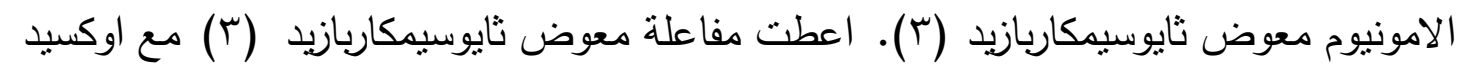

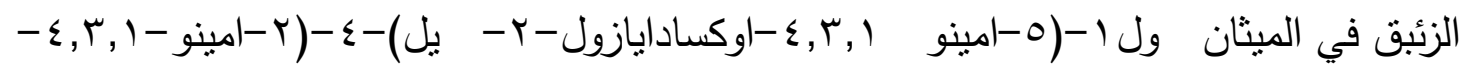

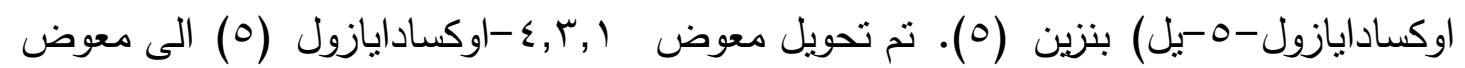

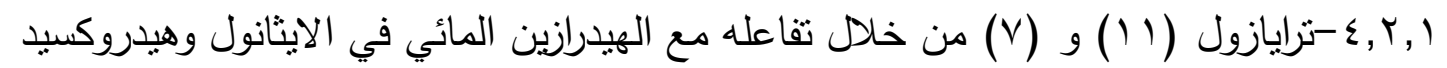

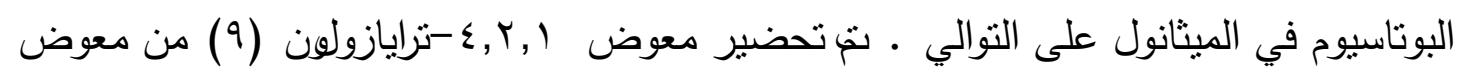

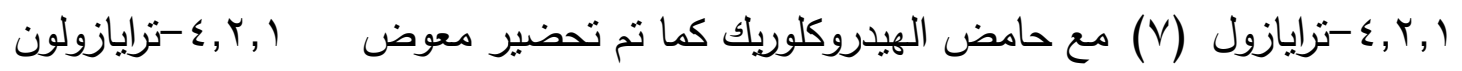

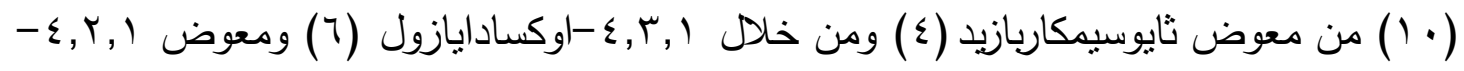

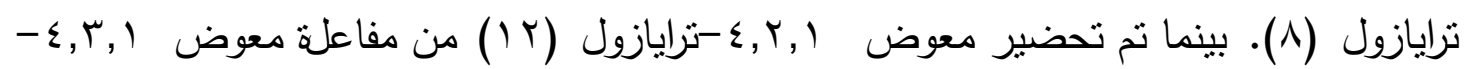

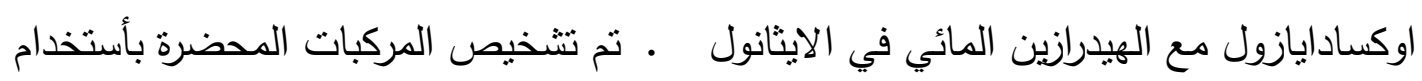
طيف IR والطرق الفيزياوية.

\section{ABSTRACT}

In this paper the synthesis of some 1,4-bis-(substituted1,3,4oxadiazoles and 1,2,4-trizoles) benzene from terephthalic acid is reported. Terephthalic acid was esterified with absolute ethanol in presence of 
concentrated sulfuric acid to give ethyl terephthalate (1) which was converted to acid hydrazide (2) with hydrazine hydrate in ethanol. The acid hydrazide (2) was treated with phenyl isothiocyanate to give substituted thiosemicarbazide(4), while it's reaction with ammonium thiocyanate gave substituted thiosemicarbazide (3). Treatment of substituted thiosemicarbazide (3) with mercury oxide in methanol gave 1(5-amino-1,3,4-oxadiazol-2-yl)-4-(2-amino-1,3,4-oxadiazol-5-yl)benzene (5). Compound (5) was treated with hydrazine hydrate in ethanol and with potassium hydroxide in methanol to give substituted 1,2,4-trizole (11) and (7) respectively. 1,2,4-trizolone (9) was synthesized from substituted 1,2,4- triazole (7) with hydrochloric acid. Substituted 1,2,4triazole (10) was obtained from substituted thiosemicarbazide (4) via 1,3,4-oxadiazole (6) and substituted triazole (8) substituted 1,2,4 triazole (12). The structures of synthesised compounds were confirmed by IR, UV and physical means.

\section{Introduction}

1,2,4-Triazole derivatives are found to be associated with various biological activities such as anticonvulsant ${ }^{(1)}$, antifungal ${ }^{(2)}$, anticancer ${ }^{(3)}$, anti-inflammatory ${ }^{(4)}$ and antibacterial properties ${ }^{(5)}$. Several compounds containing 1,2,4-triazole rings are well known as drugs ${ }^{(6)}$. For example, fluconazole is used as an antimicrobial drug, while vorozole, letrozole and anastrozole are non-steroidal drugs used for the treatment of cancer and loreclezole is used as an anticonvulsant ${ }^{(7)}$.

1,2,4-Triazoline-5-thione can be obtained by cyclization of 1formylthiosemicar- bazide in a $2 \mathrm{M}$ sodium carbonate solution ${ }^{(8)}$.

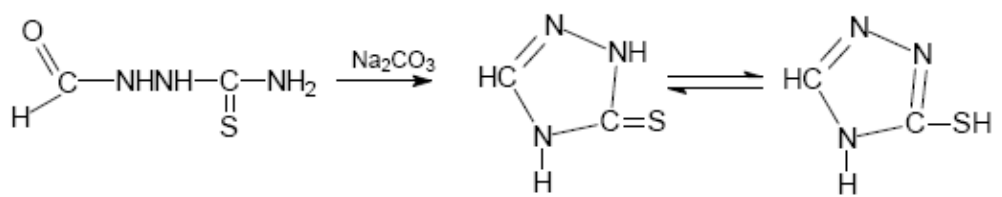

Substituted 1,2,4-triazole was synthesised form the reaction of diazonium salt with p-Toluene sulfonyl methyl isocyanide ${ }^{(9)}$ as the following compound.<smiles>CN(C)c1ccc(-n2cnc(C(=O)O)n2)cc1</smiles>

Substituted 1,3,4-oxadiazoles are of considerable pharmaceutical and biological interest ${ }^{(10)}$. They have been shown to possess muscle relaxant, antimitotic, analgesic, anti-inflammatory ${ }^{(11)}$, anticonvulsive ${ }^{(12)}$, diuretic 
and anti-emetic properties ${ }^{(13)}$. They also possess tranquilizing, antitubercular, hypoglycemic, herbicidal, antiviral ${ }^{(14)}$, amoebicidal, insecticidal, hypnotic and sedative activities. 2-Amino-5[2-(phenylthio) phenyl]-1,3,4-oxadiazole was synthesized from 2-(Phenylthio) benzoic acid hydrazide in dioxane sodium bicarbonate and cyanogene bromide $^{(15)}$.

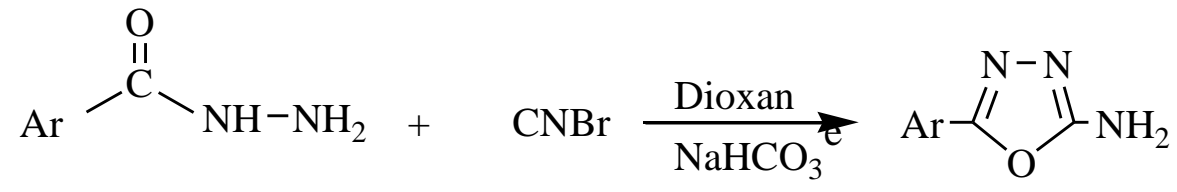<smiles>Cc1ccccc1Sc1ccccc1</smiles>

5-Aryl-2-(2-methyl-4-nitro-1-imidazomethyl)-1,3,4-oxadiazoles were prepared by microwave irradiation of 2-methyl-4-nitro-1imidazoacethydrazide with appropriate carboxylic acids in the presence of phosphorousoxy chloride ${ }^{(16)}$.<smiles>Cc1nc([N+](=O)[O-])cn1CC(=O)NN</smiles><smiles>Cc1nc([N+]([O-])OC(C)(C)C)cn1Cc1nnc([Al])o1</smiles>

\section{EXPERIMENTAL:}

All chemicals were purchased from Fluka and BDH Chemical Ltd. The melting points were measured on an Electrothermal 9300 Engineering LTD and are uncorrected. IR spectrum were recorded on Infrared Spectrophotometer Model Tensor 27, Bruker Co., Germany, using $\mathrm{KBr}$ discs. The UV spectrum were recorded on UV-Visible Shimadzu 1601 Spectrophotometer using ethanol as a solvent .

\section{Diethyl terephthalate ${ }^{(17)}(1)$}

To a mixture of $(0.01 \mathrm{~mol}, 1.66 \mathrm{~g})$ of terephthalic acid, $(50 \mathrm{ml})$ absolute ethanol, (5 ml) concentrated sulfuric acid was added with cooling. The mixture was refluxed for $(8 \mathrm{hrs})$ the formed precipitate was treated with $20 \%$ NaHCO3 the white precipitate was filtered off and recrystallized from ethanol-water $(1: 1)$.

Terephthalic acid hydrazide ${ }^{(18)}(2)$

The mixture of $(0.1 \mathrm{~mol}, 5 \mathrm{ml})$ of hydrazine hydrate was added to $(0.01 \mathrm{~mol}, 2.22 \mathrm{~g})$ of ester (1) in ethanol (30 ml) was refluxed for (12 hr) 
the solvent was evaporated under vaccum. The brown precipitate was filtered off and recrystallized from ethanol.

\section{1,4-Bis(1-carbonyl thiosemicarbazaide)benzene ${ }^{(19)}(3)$}

A mixture of (0.01 mol,1.66 g) of compound (2) (0.02 mol, $1.52 \mathrm{~g})$ of ammonium thiocyanate and $(5 \mathrm{ml})$ of concentrated hydrochloric acid was refluxed for $(8 \mathrm{hr})$ on cooling white solid crystals ,were formed filtered off, dried and recrystallized from ethanol-water.

\section{1,4-Bis(4-phenyl-1-carbonyl thiosemicarbazaide)benzene ${ }^{\left(r^{*}\right)}$ (4)}

Compound (2) (0.01 mol,1.66 g) was added to (0.02 mol, $2.7 \mathrm{~g})$ phenyl isothiosyanate and $(50 \mathrm{ml})$ ethanol. The mixture was refluxed for $(10 \mathrm{hr})$ and cooled, filtered, recrystallized from ethanol-water.

\section{1-(2-amino-1,3,4-oxadiazole-5-yl)4-(5-amino-1,3,4-oxadiazole-2-yl) benzene (5).}

1-(2-phenylamino-1,3,4-oxadiazole-5-yl) 4-(5-phenylamino-1,3,4-oxadiazole-2-yl)benzene ${ }^{(r)}(6)$

A mixture of $(0.02 \mathrm{~mol})$ thiosimecarbazide $(3,4)$ and $(0.02 \mathrm{~mol}) \mathrm{HgO}$, in the $(25 \mathrm{ml})$ methanol was refluxed for $(6 \mathrm{hrs})$ and then mixture was filtered while hot. The solvent was evaporated and the product crystallized from ethanol. Tables $(1,2)$

\section{1-(5-methoxy-1,2,4-triazol-3-yl)-4-(3-methoxy-1,2,4-triazole-5-yl)} benzene(7).

1-(4-phenyl-5-methoxy-1,2,4-triazol-3-yl)-4-(3-methoxy-4-phenyle1,2,4-triazole-5-yl)benzene ${ }^{(10)}(8)$.

To a suspension of compound $(5,6)(0.75 \mathrm{~mol})$ in methanol $(20 \mathrm{ml})$ potassium hydroxide $(0.35 \mathrm{~mol})$ was added. The solution was refluxed for (16 hrs). After cooling the reaction mixture was neutralized with acetic acid. The solvent was evaporated under reduced pressure and the residue was recrystallized from ethanol. Tables $(1,2)$

\section{1-(5-1,2,4-triazolone-5-yl)-4-(3-1,2,4-triazolone-5-yl)benzene(9).} 1-(4-phenyl-5-1,2,4-triazolone-3-yl)-4-(4-phenyl-3-1,2,4-triazolone-5yl)benzene ${ }^{(10)}(10)$

Compound $(7,8) \quad(0.14$ mol $)$ was suspended in concentrated hydrochloric acid $(10 \mathrm{ml})$ then refluxed for $(4 \mathrm{hrs})$. The mixture was cooled to room temperature and the precipitate was filtered off and crystallized from ethanol. Tables $(1,2)$. 
1-(4,5-diamino-1,2,4-triazol-3-yl)-4-(3,4-diamino-1,2,4-triazole-5-yl) benzene(11).

1-(4-amino-5-aminophenyl-1,2,4-triazole-3-yl)-4-(3-aminophenyl-4amino-1,2,4-triazol-5-yl)benzene ${ }^{(10)}(12)$.

To a suspension of $(5,6)(0.14 \mathrm{~mol})$ in ethanol $(2 \mathrm{ml})$, hydrazine hydrate $(0.28 \mathrm{ml})$ was added. The reaction was heated under reflux for ( $20 \mathrm{hrs}$ ), cooled and acidified with cold aqueous $3 \mathrm{~N}$ hydrochloric acid. The mixture was extracted with ether and the organic layer was washed with water and dried over sodium sulfate, filtered off, the solvent was evaporated under reduced pressure and the residue was recrystallized from ethanol. Table $(1,2)$.

Table (1): Melting points, color, $\%$ yield and $R_{f}$ for the synthesized compounds

\begin{tabular}{|c|c|c|c|c|}
\hline $\begin{array}{c}\text { Comp. } \\
\text { No. }\end{array}$ & m.p. ${ }^{\circ} \mathrm{C}$ & Color & Yield $\%$ & $\mathrm{R}_{\mathrm{f}(\text { Ethanol) }}$ \\
\hline 1 & $214-215$ & Brown & 83 & 0.89 \\
\hline 2 & 283 & yellow & 85 & 0.91 \\
\hline 3 & $132-133$ & Dark brown & 63 & 0.81 \\
\hline 4 & $239-240$ & Pale yellow & 82 & 0.76 \\
\hline 5 & $201-202$ & Pink & 82 & 0.78 \\
\hline 6 & $195-196$ & Orange & 87 & 0.74 \\
\hline 7 & $132-133$ & Yellow & 67 & 0.79 \\
\hline 8 & $121-123$ & brown & 79 & - \\
\hline 9 & $278-280$ & Dark orange & 76 & 0.85 \\
\hline 10 & $262-264$ & Yellow & 88 & 0.79 \\
\hline 11 & $306-307$ & Brown & 77 & 0.90 \\
\hline 12 & $287-288$ & Pale brown & 78 & 0.93 \\
\hline
\end{tabular}

\section{RESULTS AND DISCUSSION:}

In this paper the synthesis of some substituted 1,3,4-oxadiazoles and 1,2,4-triazoles is reported Scheme (4). Terephthalic acid was esterified with absolute ethanol in presence of concentrated sulfuric acid to give ester (1). The IR spectrum shows absorption bands $\square \mathrm{cm}^{-1}$ at $1741(\mathrm{C}=\mathrm{O})$, 3060 (CH-aromatic) 2950 (CH-aliphatic). Ester (1) was converted into acid hydrazide (2) by its reaction with hydrazine hydrate in ethanol. The IR spectrum shows absorption bands at $1696(\mathrm{C}=\mathrm{O}), 3390(\mathrm{NH}), 3030$ (CH-aromatic). Acid hydrazide (2) was treated with ammonium thiocyanate and phenyl isothiocyanate in absolute ethanol to give compounds (3 and 4) respectively. The proposed reaction mechanism of thiosemicarbazide formation is follows ${ }^{(\Upsilon r)}$ :

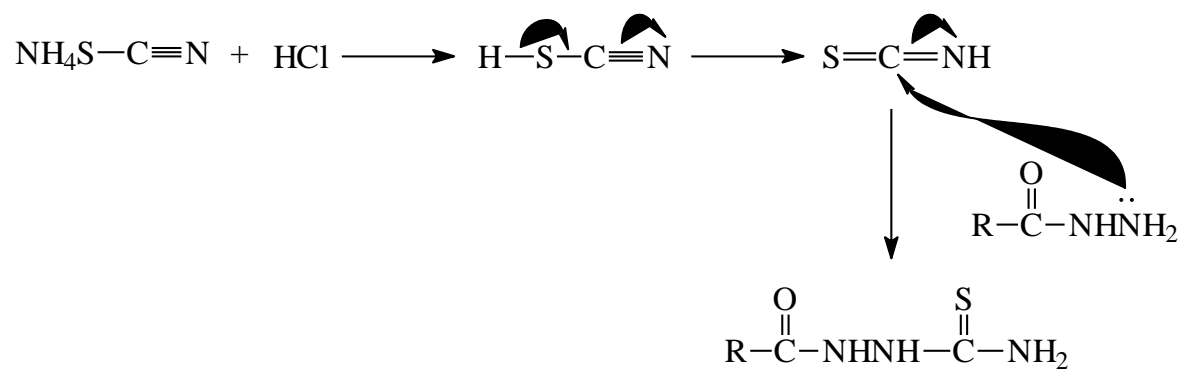

Scheme-1- 
IR spectrum of compound (3) shows absorption bands at $1690(\mathrm{C}=\mathrm{O})$, $3320(\mathrm{NH}), 1125(\mathrm{C}=\mathrm{S})$ while compound (4) show absorption at 1692 $(\mathrm{C}=\mathrm{O}), 3350,(\mathrm{NH}), 1140(\mathrm{C}=\mathrm{S})$. The proposed mechanism of the conversion of thiosemicarbazides $(3,4)$ to $1,3,4$-oxadiazoles $(5,6)$ as follows :

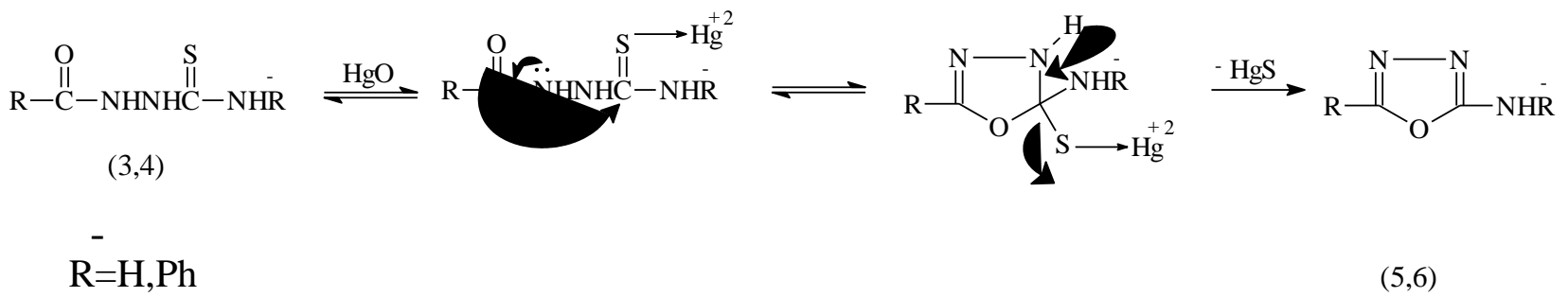

Scheme-2-

1,3,4-Oxdiazole (5) was obtained by cyclization of substituted thiosemicarbazide(3). The IR spectrum of compound (5) shows absorption bands at $\mathrm{vcm}^{-1}, 1622(\mathrm{C}=\mathrm{N}), 3390,3325,\left(\mathrm{NH}_{2}\right), 3030(\mathrm{CH}-$ aromatic), 1124 (C-O-C).

The 1,3,4-oxadiazole (6) was synthesized from thiosemeicarbazied (4) by its reaction with mercuric oxide in methanol. The IR spectrum of 1,3,4oxadiazole(6) shows absorption bands at $v \mathrm{~cm}^{-1}, 1632(\mathrm{C}=\mathrm{N}), 3410,3356$, $\left(\mathrm{NH}_{2}\right), 3050$ (CH-aromatic), 1124, 1245 (C-O-C).1,3,4-Oxadiazoles (5,6) undergo rearrangement with methanol, potassium hydroxide to give1,2,4triazoles $(7,8)$.

The proposed mechanism of the conversion of 1,3,4-oxadiazoles $(5,6)$ to 1,2,4-triazoles $(7,8)$ as follows:<smiles>Nc1nnc([Al])o1</smiles>

$(5,6)$

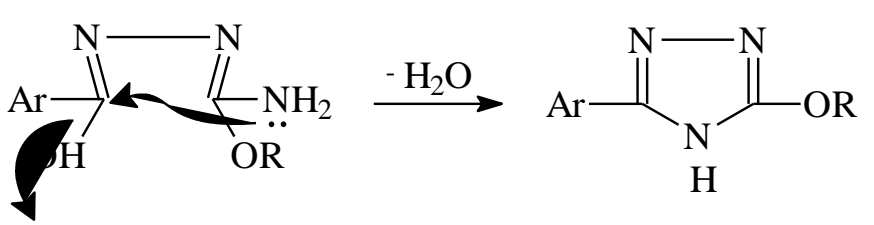

$(7,8)$

Scheme-3-

The IR spectrum of compound (7) shows absorption bands at $v \mathrm{~cm}^{-1}$, $1636(\mathrm{C}=\mathrm{N}), 3050(\mathrm{CH}$-aromatic), 2870, 2912 (CH-aliphatic), 1150, 1092 (C-O-C) while compound (8). shows absorption bands at $\mathrm{vcm}^{-1}, 1641$ $(\mathrm{C}=\mathrm{N}), 3060$ (CH-aromatic), 2890, 2966 (CH-aliphatic), 1180,1052 (C$\mathrm{O}-\mathrm{C})$.

Acid hydrolysis of compounds $(7,8)$ provided triazolones $(9,10)$ The IR spectrum of compound (9) shows absorption bands at $v \mathrm{~cm}^{-1}, 1698(\mathrm{C}=\mathrm{O})$, 3050 (CH-aromatic), $1626(\mathrm{C}=\mathrm{N}), 3185(\mathrm{NH})$. The IR spectrum compound (10) shows absorption bands at $\mathrm{vcm}^{-1,}, 1710(\mathrm{C}=\mathrm{O}), 3030(\mathrm{CH}-$ aromatic), $1636(\mathrm{C}=\mathrm{N}), 3135(\mathrm{NH})$. 
The reaction of compounds $(5,8)$ with hydrazine hydrate in ethanol gave substituted 1,2,4-triazoles $(11,12)$ The IR spectrum of compound (11) shows absorption bands at $\mathrm{vcm}^{-1}, 3070(\mathrm{CH}$-aromatic), $1632(\mathrm{C}=\mathrm{N})$, $3410,3362\left(\mathrm{NH}_{2}\right)$ IR spectrum of compound (12) shows absorption bands at $\square \mathrm{cm}^{-1} 3051$ (CH-aromatic), $1628(\mathrm{C}=\mathrm{N}), 3390 \quad\left(\mathrm{NH}_{2}\right)$. The U.V. spectrum data where due to $\mathrm{n}-\square^{*}$ and $\square-\square^{*}$ transitions ${ }^{(23)}$. Table (2).

Table (2): IR and U.V spectrum data for the synthesised compounds

\begin{tabular}{|c|c|c|}
\hline $\begin{array}{c}\text { Comp. } \\
\text { No. }\end{array}$ & $\square \mathrm{cm}^{-1}, \mathrm{KBr}$ & $\begin{array}{c}\text { U.V. } \\
\square \text { max } \\
\text { EtOH }\end{array}$ \\
\hline 1 & $1741(\mathrm{C}=\mathrm{O}), 3060(\mathrm{CH}$-aromatic),2950 (CH-aliphatic) & 250,324 \\
\hline 2 & $1696(\mathrm{C}=\mathrm{O}), 3390(\mathrm{NH}), 3030(\mathrm{CH}$-aromatic $)$ & 241,342 \\
\hline 3 & $1690(\mathrm{C}=\mathrm{O}), 3320(\mathrm{NH}), 1125(\mathrm{C}=\mathrm{S})$ & 225,318 \\
\hline 4 & $1692(\mathrm{C}=\mathrm{O}), 3350(\mathrm{NH}), 1140(\mathrm{C}=\mathrm{S})$ & 234,346 \\
\hline 5 & $1622(\mathrm{C}=\mathrm{N}), 3390\left(\mathrm{NH}_{2}\right), 3030(\mathrm{CH}$-aromatic $), 1124$ ( C-O-C) & 242,358 \\
\hline 6 & $1632(\mathrm{C}=\mathrm{N}), 3410\left(\mathrm{NH}_{2}\right), 3050(\mathrm{CH}$-aromatic $), 1254$ ( C-O-C) & 212,320 \\
\hline 7 & $1636(\mathrm{C}=\mathrm{N}), 3050(\mathrm{CH}$-aromatic),2912 (CH-aliphatic),1150 ( C-O-C) & 219,298 \\
\hline 8 & $1641(\mathrm{C}=\mathrm{N}), 3060(\mathrm{CH}-$ aromatic),2960 (CH-aliphatic),1180 ( C-O-C) & 217,288 \\
\hline 9 & $1698(\mathrm{C}=\mathrm{O})$ ring,3050(CH-aromatic),1626 $(\mathrm{C}=\mathrm{N}), 3185(\mathrm{NH})$ & 232,322 \\
\hline 10 & $1710(\mathrm{C}=\mathrm{O}), 3030(\mathrm{CH}$-aromatic $), 1636(\mathrm{C}=\mathrm{N}), 3135(\mathrm{NH})$ & 256,313 \\
\hline 11 & $3070(\mathrm{CH}$-aromatic $), 1632(\mathrm{C}=\mathrm{N}), 3410\left(\mathrm{NH}_{2}\right)$ & 207,250 \\
\hline 12 & $3051\left(\mathrm{CH}\right.$-aromatic),1628 $(\mathrm{C}=\mathrm{N}), 3390\left(\mathrm{NH}_{2}\right)$ & 233,282 \\
\hline
\end{tabular}



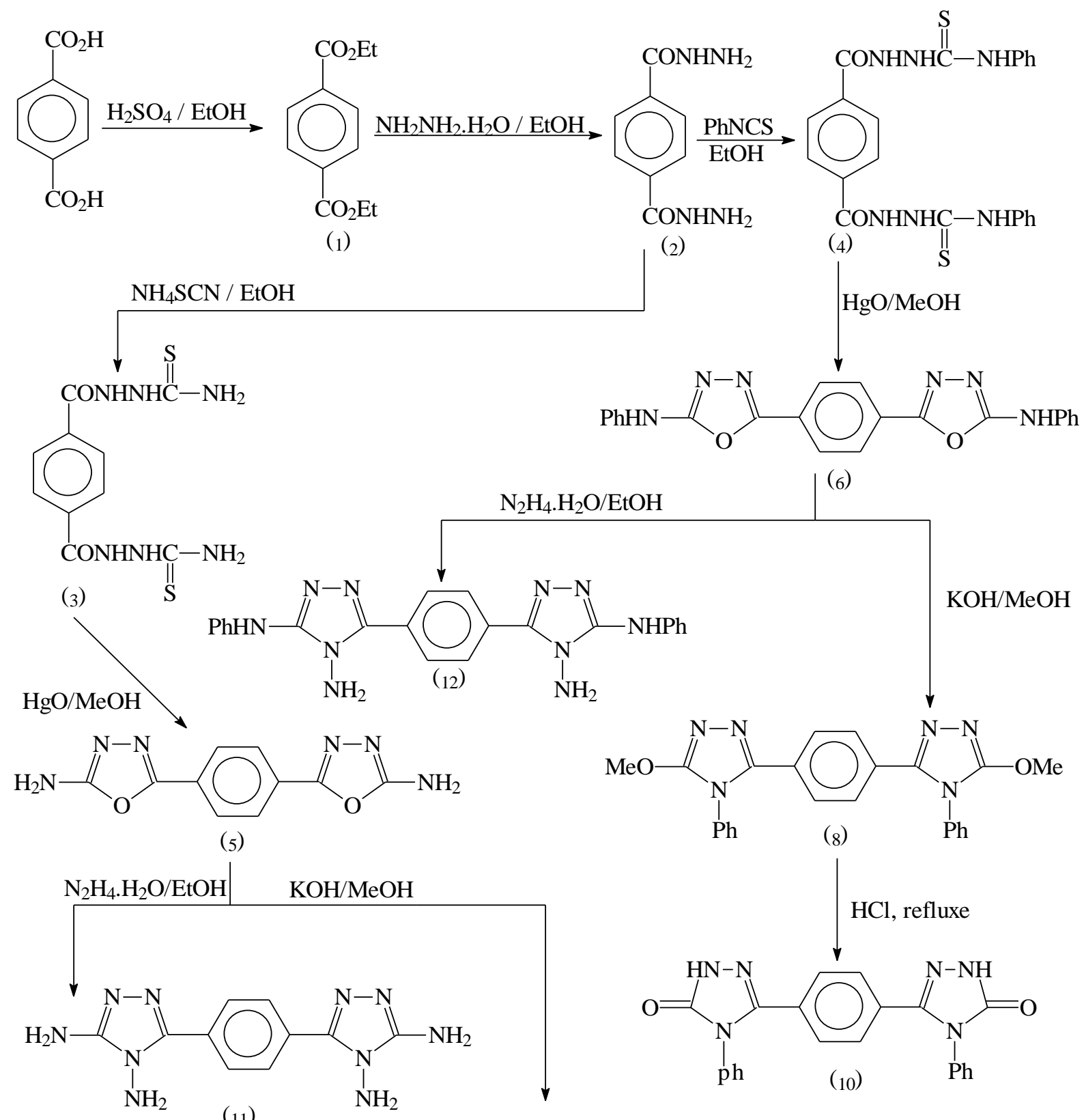

(11)<smiles>COc1nnc(-c2ccc(-c3nnc(OC)[nH]3)cc2)[nH]1</smiles><smiles>O=c1[nH]nc(-c2ccc(-c3n[nH]c(=O)[nH]3)cc2)[nH]1</smiles>

(9)

Scheme -4- 


\section{References}

1) A. Cansiz, M. Koparir and A. Demirdag, (2004), "Synthesis of some new 4,5-substituted-4H-1,2,4-triazole-3-thiol derivatives", Molecules, 9, 204-212.

2) S. R. El-Zemity, A. M. El-Shazly and E. A. Kadous, (2006), "Fungicidal and bactericidal potential of (1H-1,2,4-triazol-1-yl methyl) phenols, anilines, N-alkyl, and N,N-dialkyl anilines", J. A. Sce. Research, 2(12):1314-1318.

3) J. Salimon, N. Salih, A. Hameed, H. Ibraheem and E. Yousif., (2010), "Synthesis and antibacterial activity of some new 1,3,4oxadiazole and 1,3,4-Thiadiazole derivatives', J. A. Sce. Research, 6(7):866-870.

4) M. Alkan, H. Yuksek, O. Gursoy-Kol and M. Calapoglu, (2008), "Synthesis, acidity and antioxidant properties of some novel 3,4disubstituted-4,5-dihydro-1H-1,2,4-triazole-5-one derivatives', Molecules. 13, 107-121.

5) G. Sun, X. P. Hui, P. F. Xu, Z. Y. Zhang and Z. W. Guan, (2007), "Synthesis of novel biphenyl tetrazole derivatives containing 5methylisoxazole substituted 1,2,4triazole', J. Chinese. Chemical. Soc., 54, p.795-801.

6) Kahveci, (2005), "synthesis of 4-amino-4,5-dihydro-1H-1,2,4triazole-5-ones and their isatin-3-imine derivatives", Molecules, 10, 376-382.

7) H. Chu, X. W. Sun, Z. Y. Zhang, Z. C. Li and R. A. Liao, (1999), "Synthesis and biological activities of w-heterocyclyl-w- $(1 \mathrm{H}-1,2,4-$ triazol-1-yl) acetophenones', Chin, Chem. Vol. 10, No. 5, pp. 361 364.

8) K. M. Daoud and M. A. Eisa, (2005), "Synthesis of some substituted multinuclear 1,3,4-oxadiazoles and 1,3,4-thiadiazoles', Nat. J. Chem., Vol. 19, 405.

9) V. V. Ramana, (2005), "p-Toluene sulfonyl methyl isocyanide (TOSMIC)", Syn. Lett, 2, 363-364.

10) K. M. Daoud, A. W. Al-Obaydi, M. J. Mohammed, (2008), "Synthesis and anti-bacterial activity of some new 1,3,4oxadiazoles and 1,3,4-thiadiazoles', Tikrit. J.Vol13., No.(1)., 147151.

11) A. A. Kadi, N. R. El-Brollosy, O. A. Al-Deeb, E. E. Habib, T. M. Ibrahim, A. A. El-Eman, (2007), "Synthesis antimicrobial and antiinflammatory activities of novel 2-(1-adamantly-5-substituted1,3,4-oxadiazoles and 2-(1-adamantyl amino)-5-substituted-1,3,4thiadiazoles', European J. of Medicinal Chemistry, 42, 235-242. 
12) A. O. Maslat, M. Abussaud, H. Tashtoush, M. Al-Talib, (2002), "Synthesis antibacterial antifungal and geotaxis activity of bis1,3,4-oxadiazole derivatives", pot. J. Pharmacol, 54, 55-59.

13) K. M. Daoud, M. A. Eisa, (2002), "Synthesis of some substituted 1,3,4-oxadiazoles, thiadiazoles and 1,2,4-triazoles from 4aminobenzoic acid with expected biological activity', , Natural journal of chemistry., Vol. (7), 438-445.

14) M. Belkadi and A. A. Othman, (2006), "A common route to the synthesis of 1,3,4-oxadiazole-2-thione and 1,2,4-triazole-3-thiols derivatives of trioses and pentoses as models for a cyclic $\mathrm{C}$ nucleosides', Arkivoc, (Xi)183-195.

15) Almasirad, N. Vousooghi, S. A. Tabatabai, A. Kebriaeezadeh and A. Shafiee, (2007), "Synthesis anticonvulsant and muscle relaxant activities of substituted 1,3,4-oxadiazole, 1,3,4-thiadiazole and 1,2,4-triazole", Act. Chem. Solv., 54, 317-327.

16) Frank, K. S. Girish and B. Kalluraya, (2007), "Solvent-free microwave-assisted synthesis of oxadiazoles containing imidazole moiety', J. Chem. Soc., Vol. 119, No. 1, pp. 41-46.

17) E. R. Bochman, C. M. Mc-Closkey and J. A. Seneker, (1947), "8-Nitrocinchoninic acids and related substances", J. Am. Chem. Soc., 69, 380.

18) H. Rajak, M. D. Kharya and P. Mishrd, (2007), "Synthesis of some novel oxadiazole and oxadiazoline analogues for their antiinflammatory activity", Yakugaku, Zassshi, 127(10), 1757-1764 .

19) M. T. Wu, (1972), "Synthesis of some heterocyclic derivatives of 3,5-dinito-o-toluic acid", J. Heterocyclic Chem., 9, 31.

20) S. L. Vasoya, D. J. Paghdra, P. T. Chovatia and H. S. Joshi, (2005), "Synthesis of some new thiosemicarbazide and 1,3,4-thiadiazole heterocycles bearing benzo [b] hiophene nucleus as potent antitubercular and antimicraobialagents', J. of Science, Islamic Republic of Iran, 16(1):33-36.

21) R. S. Sharma and S. C. Bahel, (1982), "Synthesis of aryloxyl/aryl acetyl thiosemicarbazides, substituted 1,3,4-oxadiazoles, 1,3,4thiadiazoles, 1,2,4-triazoles and related compounds as potential fungicides', J. Indian Chem. Soc., LIX, 877.

22) A. N. Ali, (2006), "Synthesis and study of some substituted five membered heterocyclic compounds", Ph. D. Thesis, Mosul University, Mosul-Iraq.

23) R. M. Silverstein, G. C. Bassler and T. C. Movrill, (1981) spectrometric identificatiov of organic compounds, $4^{\text {th }}$ ed. John Wiley and sons, p. 308. 